\title{
Inheritance of Resistance in Lima Bean to Phytophthora phaseoli, the Causal Agent of Downy Mildew of Lima Bean
}

\author{
Luisa Santamaria ${ }^{1}$ \\ Department of Botany and Plant Pathology, North Willamette Research \& \\ Extension Center, Oregon State University, Aurora, OR 97002
}

\section{Emmalea G. Ernest, Nancy F. Gregory, and Thomas A. Evans \\ Department of Plant and Soil Sciences, University of Delaware, Newark, DE 19716}

Additional index words. Phaseolus lunatus, oomycete, screening for disease resistance, germplasm collection, single dominant gene

\begin{abstract}
The oomycete Phytophthora phaseoli is one of the most threatening pathogens of lima bean (Phaseolus lunatus) in the humid Mid-Atlantic United States. In the last 60 years, $P$. phaseoli has evolved to overcome genetic resistance in the host and several physiological races have been identified during the last 6 decades. Six physiological races $A, B, C, D, E$, and $F$ have been identified over the years. Only race $F$ has been detected in the field over the past decade. Identifying and characterizing sources of resistance to this pathogen and determining the nature of resistance were the main objectives. Eight commercial cultivars and 35 germplasm accessions of $\boldsymbol{P}$. lunatus were evaluated for their reaction to races $E$ and $F$. Four commercial cultivars and four accessions with resistance to race $E$, and two cultivars and four accessions with resistance to race $F$ were identified. None of the germplasm evaluated were resistant to both races. Five populations of F2 plants and a recombinant inbred line (RIL) population were produced and inoculated to investigate the inheritance of resistance to races $E$ and $F$. Resistance to races $E$ and $F$ was determined to be conferred by single, independent, dominant genes.
\end{abstract}

Downy mildew, incited by $P$. phaseoli Thaxt., became a major threat to lima bean $(P$. lunatus L.) production in the humid eastern United States in the 1940s. The U.S. Department of Agriculture (USDA) began breeding lima bean for resistance to downy mildew in 1948 in collaboration with the Long Island Vegetable Research Farm at Riverhead, NY (Wester and Cetas, 1959). At that time, no races or variants of the pathogen were known. A physiological race, hereafter referred to as race, is a subdivision of a pathogen species, particularly fungi, distinguished from other members of the species by specialization for pathogenicity to different cultivars of a host (Kirk et al., 2001). The use of differential cultivars has been the principal method to distinguish emerging races of $P$. phaseoli. Differential cultivars used to distinguish physiological

\footnotetext{
Received for publication 5 Jan. 2018. Accepted for publication 6 Apr. 2018.

This research was supported by USDA/AMS Award Agreement 12-25-G-0543 and USDA/ AMS Award Agreement 2-25-B-1059.

We thank Paul Layton for his work to locate and acquire seed from the wild population of $P$. polystachios. Mention of a trademark, proprietary product, or vendor does not constitute a guarantee or warranty of the product by the authors and does not imply its approval to the exclusion of other products or vendors that may also be suitable.

${ }^{1}$ Corresponding author. E-mail: luisa.santamaria@ oregonstate.edu.
}

races $\mathrm{A}, \mathrm{B}, \mathrm{C}, \mathrm{D}, \mathrm{E}$, and $\mathrm{F}$ have been reported by Evans et al. (2007).

The USDA downy mildew resistance breeding program began in 1948 and in 1958, released 'Thaxter', its first cultivar with downy mildew resistance (Wester and Cetas, 1959). The resistance in 'Thaxter' was conferred by a single dominant gene derived from the $P$. lunatus landrace PI 164155. A new race of $P$. phaseoli, which overcame the resistance in 'Thaxter', was detected in 1958 and was designated race $\mathrm{B}$ (Wester and Cetas, 1959). The landrace PI 189403 was found to be resistant to races A and B (Wester and Cetas, 1959) and was used as the resistant parent in the development of 'Dover', which was released by the USDA in 1970 (Stavely, 1991). A new race of downy mildew, designated $\mathrm{C}$, which overcame the resistance in Dover, was identified in 1969 when the cultivar was still in trial (Wester, 1970). The PI 195342 was found to be resistant to the new race $\mathrm{C}$ as well as races $\mathrm{A}$ and $\mathrm{B}$ and were used in the development of the germplasm C-171, which was released in 1973 and was resistant to races $\mathrm{A}, \mathrm{B}$, and $\mathrm{C}$ (Thomas and Fisher, 1979). In 1975, a fourth race of downy mildew, designated $\mathrm{D}$, was identified. PI 195342, used since 1972 as a source of resistance to races $\mathrm{A}, \mathrm{B}$, and $\mathrm{C}$, was susceptible to race $\mathrm{D}$ (Thomas and Blount, 1976). A germplasm release designated B2C (PI 549515), made jointly by USDAARS and the Delaware Agricultural Experiment Station in 1976, had resistance to races $\mathrm{A}, \mathrm{B}, \mathrm{C}$, and $\mathrm{D} . \mathrm{B} 2 \mathrm{C}$ arose from crosses of PI 195342, 'Bridgeton' and US 1068, a sibling of 'Bridgeton' (Thomas and Fisher, 1980).

The lima bean improvement program conducted by USDA-ARS, Beltsville, between 1949 and 1989, resulted in significant improvement in quality, yield, and most importantly, resistance to the four prevalent races of $P$. phaseoli (Evans et al., 2007; Kee et al., 1997). From this program, more than 30 cultivars and germplasm releases were made available to plant breeders, seed companies, and producers (Stavely, 1991).

For 20 years, no new races of $P$. phaseoli were detected in the Mid-Atlantic region (MAR). However, in 1995, a new race of $P$. phaseoli, designated race $\mathrm{E}$, was detected in Delaware and became more widely distributed than race D (Evans et al., 2002). In 2000, an epidemic incited by race $E$ resulted in an estimated loss of $40 \%$ of Delaware lima bean production, equal to a farm gate value loss of $\$ 3,000,000$ (Scuse and Feurer 2003). Then, race $\mathrm{F}$ of $P$. phaseoli was first detected in 2000 (Evans et al., 2005) and was the most prevalent race by 2004. Because of the emergence of the $\mathrm{E}$ and $\mathrm{F}$ races, it is important to evaluate the reaction of the cultivars most commonly grown in Delaware to these new races and identify possible sources of resistance. There are currently no cultivars with resistance to both races $\mathrm{E}$ and $\mathrm{F}$ of $P$. phaseoli, resistance to race $\mathrm{F}$ is needed in horticulturally acceptable germplasm for use in the humid MAR.

In 2004, a lima bean breeding program was re-initiated at the University of Delaware to develop new cultivars for the MAR, including cultivars with resistance to races $\mathrm{E}$ and $\mathrm{F}$ of $P$. phaseoli. This study was undertaken to support the disease resistance breeding goals of the program. The first objective of was to evaluate the reactions of commercial cultivars to races $\mathrm{E}$ and $\mathrm{F}$ of $P$. phaseoli in the field. The second objective was to identify sources of resistance to those races from diverse germplasm, including cultivars, germplasm releases, and landraces. The third objective was to determine the pattern of inheritance of resistance to these two races to facilitate incorporation of resistance genes into commercially acceptable small, flat-seeded (baby), and large, plumpseeded (Fordhook), lima bean cultivars for production in the MAR.

\section{Materials and Methods}

Maintenance of physiological races of $P$. phaseoli. Isolates of $P$. phaseoli characterized as races $\mathrm{E}$ and $\mathrm{F}$ were maintained in pure cultures for long-term storage at $20{ }^{\circ} \mathrm{C}$ in screw-cap test tubes containing sterile water and corn (Zea mays L.) and/or cucumber (Cucumis sativus L.) seeds as substrates. Isolates of $P$. phaseoli races $\mathrm{E}$ and $\mathrm{F}$ were reactivated by transferring to the semiselective media lima bean agar (Calvert et al., 1960) or modified pea agar (Dance et al., 1975). After 
transfer, the cultures were maintained in an incubator set at $20^{\circ} \mathrm{C}$.

Inoculum production and hypocotyl screening of germplasm. Inoculum of $P$. phaseoli was produced and maintained on hypocotyls of the susceptible lima bean cultivar Concentrated Fordhook. Untreated seeds were rinsed in sterile distilled water to remove any surface contaminants and to begin the imbibition process. The seeds were placed in $10-\mathrm{cm}$ plastic pots with a commercial plug and seedling mix, five to six seeds per pot, placed close together. The pots were placed on heat mats set to $26{ }^{\circ} \mathrm{C}$, on greenhouse benches. Four days after seeding when hypocotyls began to emerge, some potting mix was gently removed by hand from the pots to reveal more of the developing hypocotyls. Emerging seedlings with cotyledons were watered lightly to soften seedcoats and whenever possible, seedcoats were removed by hand. Inoculum was prepared by harvesting 7-d-old infected hypocotyls and stem material which were cut into small $(3-6 \mathrm{~mm})$ sections on a sterile surface. This material was then mixed with sterile distilled water to make a slurry. The slurry was placed onto expanding seedlings in direct contact with the new tissue. The pots were placed in a dew chamber for up to $7 \mathrm{~d}$. Symptoms of stunting and distortion typical of the disease developed within $6 \mathrm{~d}$ with abundant mycelia and sporangia produced inside of the dew chamber. The two races of $P$. phaseoli were maintained in separate digital-controlled dew chambers (Percival Scientific, Inc., Perry, IA). The dew chambers were set at a continuous $20{ }^{\circ} \mathrm{C}, 94 \% \pm 1 \%$ relative humidity, and continuous $50 \mu \mathrm{mol} \cdot \mathrm{m}^{-2} \cdot \mathrm{s}^{-1}$ of photosynthetic active radiation. When seedlings exhibited symptoms of downy mildew, the hypocotyls were harvested to prepare inoculum. Lines may be screened for resistance at the seedling emergence stage or later, during early pod set. When screened at seedling emergence, susceptible plants develop symptoms on hypocotyl tissue and resistant plants do not. For screening at the seedling emergence stage, the inoculum was prepared as previously described. For larger studies, $\approx 200 \mathrm{~g}$ of infected tissue and $1000 \mathrm{~mL}$ of water filtered by reverse osmosis were placed in a 2-L beaker and mixed thoroughly with a glass stirring rod; the suspension was refrigerated at $5{ }^{\circ} \mathrm{C}$ for $30 \mathrm{~min}$. Finally, plant tissue pieces were removed by passing the solution through a sieve (U.S. Standard test sieve No. 18). The concentration of sporangia was determined from a sample of this suspension using a hemocytometer (Bright-Line ${ }^{\circledR}$; American Optical Corporation, Buffalo, NY) and a compound microscope at $\times 200$. The suspension was adjusted to a density of $1 \times 10^{3}$ sporangia $/ \mathrm{mL}$.

Evaluation of $P$. lunatus accessions and commercial cultivars in the field for reaction to downy mildew incited by $P$. phaseoli races $E$ and $F$. A total of $43 P$. lunatus genotypes (35 accessions and eight cultivars) were screened in the field for their reaction to races $\mathrm{E}$ and $\mathrm{F}$ of the downy mildew pathogen from
2003 to 2010 . Nineteen accessions were from the USDA-National Plant Germplasm System and 16 from the International Center for Tropical Agriculture. The remaining eight were cultivars obtained from commercial seed suppliers. A species native to eastern North America, Phaseolus polystachios (L.) BSP, was also screened to determine its reaction to races $\mathrm{E}$ and $\mathrm{F}$ in the field (four plants for each race), and in a dew chamber (five plants for each race) during 2010. Seed used for screening was collected from a wild population in Maryland and subsequently submitted to the USDA-NPGS collection, accession number W636674. The species $P$. polystachios, which was not previously identified as a host of $P$. phaseoli, is closely related to lima bean (Delgado-Salinas et al., 1999).

Lima bean accessions were evaluated in the field for their reactions to two races of $P$. phaseoli separately at the University of Delaware's Agricultural Experiment Stations in Newark (race E) and Georgetown (race F) in 2004, 2005, 2006, 2009, and 2010. Plots were established during the first week of July in each year and arranged in a randomized complete block design with three replications. Each plot consisted of 4.6-m row with rows spaced $0.76 \mathrm{~m}$ apart. The cultivars selected were planted by hand or handoperated vegetable seeder, 12 seeds $/ \mathrm{m}$ row. For some cultivars with limited seed, evaluation plots were half the length (2.44 $\mathrm{m}$ row). Susceptible cultivars (Eastland race E and 184-85 race F) were planted every fifth row as controls and to facilitate pathogen spread.

Each year, plots were inoculated in early September at the newly formed pod (pin) to flat pod stage. Inoculum was prepared as previously described and applied with a backpack low-pressure manual pump sprayer (SOLO backpack sprayer, model 425; SOLO Incorporated, Newport News, VA) in the early evening when temperatures were between 18 and $21^{\circ} \mathrm{C}$. Plants were sprayed until runoff with a sporangial suspension containing $1 \times 10^{3}$ sporangia $/ \mathrm{mL}$ of $P$. phaseoli, and the inoculation was repeated $7-10 \mathrm{~d}$ later. Beginning the first night after inoculation, the plants were misted intermittently each night using Micro-Bird misting nozzles (Rain Bird Corp., Glendora, CA) from 1800 to $0600 \mathrm{HR}$ to increase humidity and leaf wetness duration. Irrigation was provided as needed throughout the season using trickle tape in Newark and overhead irrigation in Georgetown. The middle $2.3 \mathrm{~m}$ of each row was evaluated for susceptibility $10-15 \mathrm{~d}$ after the second inoculation. The plants were rated for signs of infection (white fluffy mycelium on shoot tips, pins, and flat pods) and symptoms of downy mildew (red line surrounding infected areas on pods). If necessary, confirmation of infection was made by evaluating samples morphometrically for sporangia of $P$. phaseoli using a compound microscope.

Inheritance of resistance of $F_{2}$ populations of $P$. lunatus to races $E$ and $F$ of $P$. phaseoli. To facilitate breeding for resistance to downy mildew, a study of the inheritance of resistance to races $\mathrm{E}$ and $\mathrm{F}$ of $P$. phaseoli was started. The cultivars used in the study were Cypress, Dover Tucker, Maffei 15, Jackson Wonder, and germplasm release B2C. Parents for the crosses were chosen based on their disease reaction in previous disease screening: ' $\mathrm{Cy}$ press' and 'Dover Tucker' are resistant to race $\mathrm{E}$ but susceptible to race $\mathrm{F}$, whereas 'Maffei $15^{\prime}$ and $\mathrm{B} 2 \mathrm{C}$ are susceptible to race $\mathrm{E}$ and resistant to race $\mathrm{F}$ (Table 1). 'Jackson Wonder' is susceptible to both races. Crosses were made between 'Jackson Wonder' and the resistant parents in the greenhouse. The $F_{1}$ plants from these crosses were planted in the greenhouse and the seed from each $\mathrm{F}_{1}$ plant was harvested and maintained separately during inoculation to facilitate detection of accidental self-pollination. Five $F_{2}$ populations (Tables 3-5) were screened to observe the segregation pattern of the resistance reaction. A total of $254 \mathrm{~F}_{2}$ plants from 'Jackson Wonder' (susceptible) $\times$ 'Cypress' (E resistant) and $315 \mathrm{~F}_{2}$ plants from 'Jackson Wonder' $\times$ 'Dover Tucker' (E resistant) were screened. A total of $209 \mathrm{~F}_{2}$ plants from 'Jackson Wonder' (susceptible) $\times$ 'Maffei 15' (F resistant) and $271 \mathrm{~F}_{2}$ plants from 'Jackson Wonder' (susceptible) $\times$ B2C (F resistant) were screened. From the E-resistant by E-resistant test cross 'Dover Tucker' $\times$ 'Cypress', $223 \quad \mathrm{~F}_{2}$ plants were screened. The $\mathrm{F}_{2}$ seeds were planted in $10-\mathrm{cm}$ pots in seed starter substrate and grown until hypocotyl emergence.

At the time of hypocotyl emergence from the substrate, the pots were transferred to two separate greenhouse humidity chambers with wick mats and timer-controlled misting system as described previously to provide optimal conditions for infection. The $F_{2}$ populations were inoculated with either race $\mathrm{E}$ or $\mathrm{F}$ by applying a $10-\mathrm{mL}$ suspension of $1 \times$ $10^{3}$ sporangia $/ \mathrm{mL}$ of $P$. phaseoli and at 5 and $10 \mathrm{~d}$ postemergence by spray inoculation to ensure that there were no escapes from infection. The plants were visually evaluated for infection daily over a 7-d period and infection confirmed by making scrapings of hypocotyls on microscope slides and observing the presence or absence of sporangia of P. phaseoli.

Evaluation of a population RILs of P. lunatus for resistance of downy mildew incited by $P$. phaseoli race E in 2011. A set of $121 \mathrm{~F}_{9}$ RILs from the cross 'Bridgeton' $\times$ 'Jackson Wonder' and the two parental lines were screened in the field for their reaction to race $\mathrm{E}$ of $P$. phaseoli. Ten seeds of each line were planted in the field on 6 July 2011. The plants were inoculated at the pin pod to flat pod stage with a sporangial suspension as previously described. Individual plants were rated as susceptible or resistant on 21 Sept. 20113 months later. Ratings were based on the presence of signs and symptoms of downy mildew.

Statistical analysis. Observed ratios of resistant to susceptible plants from resistant $x$ susceptible test crosses were compared with the expected ratio of 3 resistant : 1 susceptible for $\mathrm{F}_{2}$ populations and 1 resistant : 1 susceptible for the RIL population to test for monogenic 
Table 1. Results of screening for downy mildew races $\mathrm{E}$ and $\mathrm{F}$ resistance in small-seeded lima bean cultivars and germplasm accessions and Phaseolus polystachios germplasm in the field and greenhouse from 2003 to 2010 .

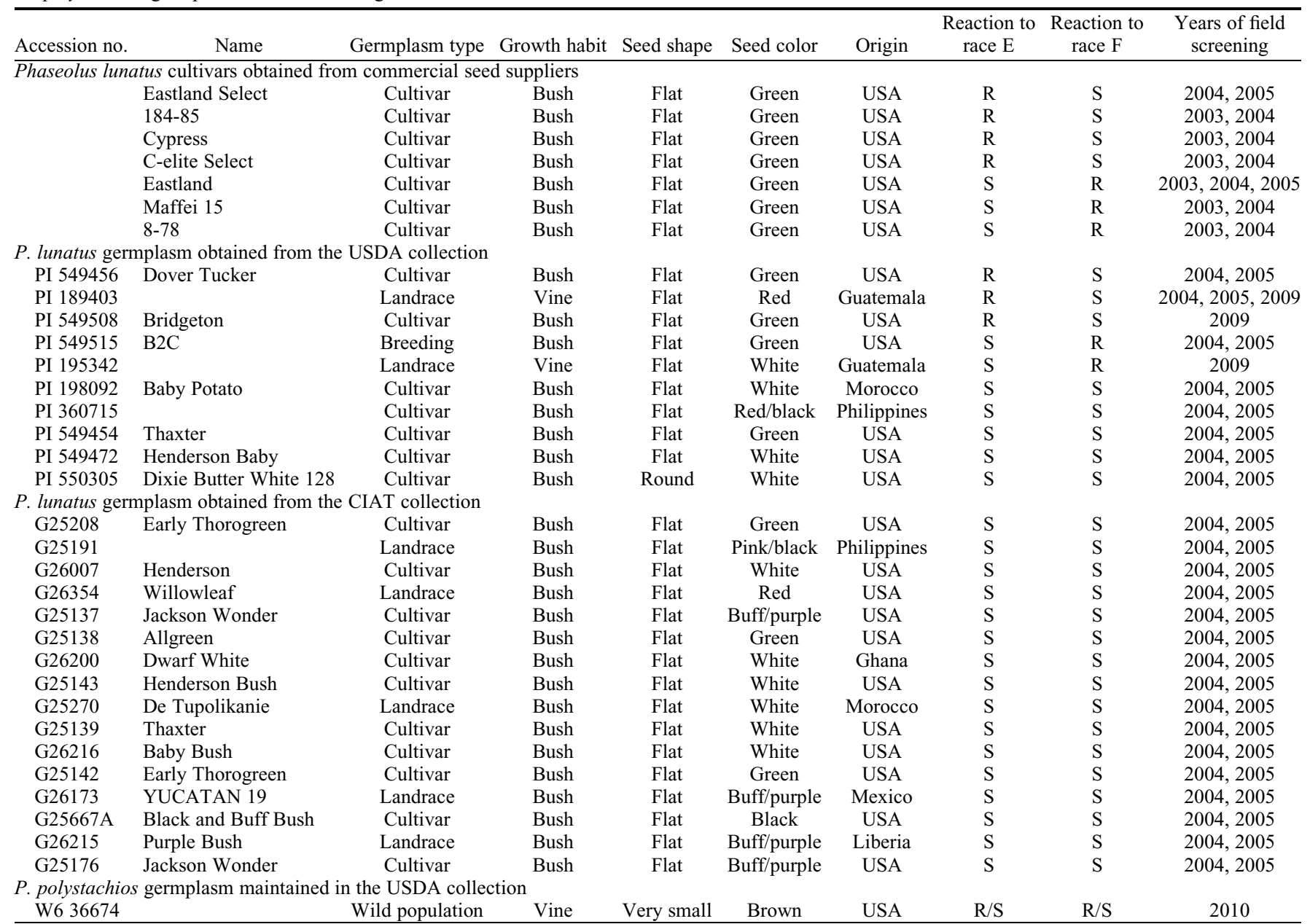

$\mathrm{R}=$ resistant reaction; $\mathrm{S}=$ susceptible reaction; CIAT $=$ International Center for Tropical Agriculture.

inheritance of resistance using the chi-square goodness of fit test. Observed ratios for resistant $\times$ resistant test crosses were compared with a 15 resistant : 1 susceptible ratio to test for independence of the resistance loci.

\section{Results}

Evaluation of germplasm for resistance to races $E$ and $F$ of downy mildew. Of the seven baby lima bean cultivars obtained from commercial seed suppliers that were screened in inoculated field plots in 200305 , four were resistant to race $\mathrm{E}$ and susceptible to race F: 'Eastland Select', '184-85', 'Cypress', and 'C-elite Select' (Table 1). Three of the commercial cultivars were resistant to race $\mathrm{F}$ and susceptible to race E: Maffei 15, 'Eastland', and '8-78'. Of the 26 small-seeded accessions screened in inoculated field plots, three were resistant to race $\mathrm{E}$ and susceptible to race $\mathrm{F}$, 'Dover Tucker' (PI 549456), PI 189403, and 'Bridgeton' (PI 549508). Two accessions, B2C (PI 549515) and PI 195342, were resistant to race $\mathrm{F}$ and susceptible to race $\mathrm{E}$. None of the accessions were resistant to both races $\mathrm{E}$ and $\mathrm{F}$.
Nine large-seeded genotypes were screened in the field for resistance to downy mildew races $\mathrm{E}$ and $\mathrm{F}$ (Table 2). The germplasm release F-169 (PI 549514) was resistant to race E but susceptible to race $\mathrm{F}$ and the germplasm release MRF-79 (PI 549524) was resistant to race F but susceptible to race E. Two other USDA Fordhook releases which had been bred for resistance to downy mildew races $\mathrm{A}, \mathrm{B}, \mathrm{C}$, or D, 'F-1072' and 'MRF 90-1', were not resistant to either race $\mathrm{E}$ or $\mathrm{F}$.

Two of four plants of $P$. polystachios that were inoculated in the field with race $E$ and three of four plants inoculated with race $F$ exhibited signs and symptoms of infection of $P$. phaseoli identical to the reaction produced on lima bean. Samples taken from these plants were confirmed morphometrically to be due to infection by $P$. phaseoli, indicating that $P$. polystachios is an alternate host for downy mildew. In later dew chamber evaluations, five of five plants inoculated at the hypocotyl stage were susceptible to race $\mathrm{E}$ and two of five plants were susceptible to race F. These preliminary results suggest that this particular wild population of $P$. polystachios has genes conferring resistance to downy mildew.

Determining the inheritance of resistance to races $E$ and $F$ of $P$. phaseoli. The two $\mathrm{F}_{2}$ populations from the crosses between downy mildew-susceptible 'Jackson Wonder' and the race E-resistant cultivars Cypress and Dover Tucker segregated in a 3:1 (resistant/ susceptible) ratio with $P>0.05$. The $\chi^{2}$ values were $2.09(P=0.1484)$ for 'Jackson Wonder' $\times$ 'Cypress' and $1.37(P=0.2421)$ for 'Jackson Wonder' $\times$ 'Dover Tucker' (Table 3), indicating that in both cultivars, a single dominant gene conferred resistance to race $\mathrm{E}$ of $P$. phaseoli. In the $\mathrm{R} \times \mathrm{R}$ cross 'Dover Tucker' $\times$ 'Cypress', all $223 \mathrm{~F}_{2}$ plants were resistant to race $\mathrm{E}$. This result does not fit a 15:1 (resistant/susceptible) ratio to suggest the presence of two independent dominant resistance genes; the $\chi^{2}$ value is 14.94 $(P=0.0001)$. The observed result suggests that these two cultivars carry the same resistance gene or two different resistance alleles at the same locus (Table 3).

Four to 10 individual plants were rated for their reaction to race $E$ for each of the 'Bridgeton' $\times$ 'Jackson Wonder' RILs and parent lines. The cultivar Bridgeton is resistant to race E and Jackson Wonder is susceptible. All of the plants in each RIL either had signs and symptoms of downy mildew (rated susceptible) or were without signs and symptoms of the disease (rated 
resistant). Sixty-nine of the lines were rated resistant and 52 were susceptible (Table 3 ), which fits a $1: 1$ segregation ratio with a $\chi^{2}$ value of $2.39(P=0.1222)$, indicating that resistance to race $\mathrm{E}$ is conferred by a single gene.

When inoculated, the $F_{2}$ populations from the crosses between 'Jackson Wonder' and the race F-resistant 'Maffei 15' and $\mathrm{B} 2 \mathrm{C}$ resulted in plants with three different disease reactions. Some plants were completely resistant, some were very susceptible (i.e., exhibited obvious mycelial growth and died), whereas others were stunted, had some tissue death, but did not die. Mycelium and sporangia of $P$. phaseoli were detectable on these stunted plants microscopically. In Table 4, the plants are categorized as either resistant or susceptible, with plants exhibiting partial resistance classified as susceptible. When classified this way, both populations fit a 3:1 (resistant/susceptible) ratio with $P>$ 0.05 . The $\chi^{2}$ value is $0.10(P=0.7490)$ for 'Jackson Wonder' $\times$ 'Maffei 15' and 1.59 $(P=0.2073)$ for 'Jackson Wonder' $\times$ B2C, indicating that both 'Maffei 15 ' and $\mathrm{B} 2 \mathrm{C}$ carry a single dominant gene which confers complete resistance to downy mildew race $\mathrm{F}$ (Table 4).

However, in Table 5, the plants are categorized as resistant, partially resistant, or very susceptible. The segregation ratio is suggestive of the presence of recessive or partially dominant genes that confer partial resistance. These partial resistance genes are masked in 'Maffei 15', B2C, and their fully resistant progeny by the single dominant gene for resistance, which makes determining the segregation ratio of the genes for partial resistance in these particular populations difficult. It is likely that 'Maffei 15' and B2C carry the same downy mildew resistance genes because 'Maffei 15' was selected from the germplasm release B2C.

\section{Discussion}

In the search for new sources of resistance for $P$. phaseoli in lima bean, screening under field and greenhouse conditions helped to identify baby lima bean cultivars with resistance to race $\mathrm{E}$ of downy mildew and others with resistance to race $\mathrm{F}$ that are suitable for commercial use in the MAR. Three of the race E-resistant cultivars, 184-85, Cypress, and C-elite Select, have become the standard commercial cultivars in the MAR. The race F-resistant cultivar Maffei 15 is also currently used in commercial production. No cultivar has been identified with resistance to both races $\mathrm{E}$ and $\mathrm{F}$. Therefore, growers cannot rely on cultivar resistance to manage this disease. The University of Delaware lima bean breeding program is actively working to develop baby lima bean cultivars with resistance to both races $\mathrm{E}$ and $\mathrm{F}$.

Germplasm of the large-seeded Fordhook type from the USDA breeding program was identified with resistance to race E (F-169) and race $\mathrm{F}$ (MRF-79). These two germplasm releases are being used in the University of Delaware lima bean breeding program to develop Fordhook cultivars with resistance to races $\mathrm{E}$ and $\mathrm{F}$ of the downy mildew pathogen.

Genes for resistance to races $\mathrm{E}$ and $\mathrm{F}$ are present in cultivars and germplasm releases

Table 2. Results of screening for downy mildew races $\mathrm{E}$ and $\mathrm{F}$ resistance in large-seeded lima bean cultivars and germplasm accessions in the field and greenhouse from 2004 to 2009 .

\begin{tabular}{|c|c|c|c|c|c|c|c|c|c|}
\hline Accession no. & Name & Germplasm type & Growth habit & Seed shape & Seed color & Origin & $\begin{array}{l}\text { Reaction to } \\
\text { race } E\end{array}$ & $\begin{array}{l}\text { Reaction to } \\
\text { race } F\end{array}$ & $\begin{array}{c}\text { Years of } \\
\text { field screening }\end{array}$ \\
\hline & MRF 90-1 & Breeding & Bush & Plump & Green & USA & $\mathrm{S}$ & $\mathrm{S}$ & 2009 \\
\hline \multicolumn{10}{|c|}{ P. lunatus germplasm obtained from the USDA collection } \\
\hline PI 549524 & MRF-79 & Breeding & Bush & Plump & Green & USA & $\mathrm{S}$ & $\mathrm{R}$ & 2009 \\
\hline PI 549464 & Fordhook 242 & Cultivar & Bush & Plump & White & USA & $\mathrm{S}$ & $\mathrm{S}$ & 2009 \\
\hline PI 549465 & Fordhook Bush & Cultivar & Bush & Plump & White & USA & $\mathrm{S}$ & $\mathrm{S}$ & 2009 \\
\hline PI 549479 & Concentrated Fordhook & Cultivar & Bush & Plump & White & USA & $\mathrm{S}$ & $\mathrm{S}$ & 2009 \\
\hline PI 549518 & Dompe 95 & Cultivar & Bush & Flat & White & USA & $\mathrm{S}$ & $\mathrm{S}$ & 2004,2005 \\
\hline
\end{tabular}

$\mathrm{R}=$ resistant reaction; $\mathrm{S}=$ susceptible reaction

Table 3. Inheritance of resistance to downy mildew race E in lima bean populations derived from crosses of cultivars Cypress, Dover Tucker, Bridgeton, and Jackson Wonder.

\begin{tabular}{|c|c|c|c|c|c|c|c|c|c|}
\hline \multirow[b]{2}{*}{ Cross } & \multirow[b]{2}{*}{ Cross type } & \multirow[b]{2}{*}{ Test ratio } & \multicolumn{2}{|c|}{ Observed plants } & \multicolumn{2}{|c|}{ Expected plants } & \multirow[b]{2}{*}{ Total } & \multirow[b]{2}{*}{$\chi^{2}$ value } & \multirow[b]{2}{*}{$P$ value } \\
\hline & & & Resistant & Susceptible & Resistant & Susceptible & & & \\
\hline Jackson Wonder $\times$ Cypress $\mathrm{F}_{2}$ & $\mathrm{~S} \times \mathrm{R}$ & $3: 1$ & 180 & 74 & 190 & 64 & 254 & 2.09 & 0.1484 \\
\hline Jackson Wonder $\times$ Dover Tucker $F_{2}$ & $\mathrm{~S} \times \mathrm{R}$ & $3: 1$ & 227 & 88 & 236 & 79 & 315 & 1.37 & 0.2421 \\
\hline Dover Tucker $\times$ Cypress $\mathrm{F}_{2}$ & $\mathrm{R} \times \mathrm{R}$ & All resistant & 223 & 0 & & & 223 & & \\
\hline Dover Tucker $\times$ Cypress $F_{2}$ & $\mathrm{R} \times \mathrm{R}$ & 15: 1 & 223 & 0 & 209 & 14 & 223 & 14.94 & 0.0001 \\
\hline Bridgeton $\times$ Jackson Wonder RIL & $\mathrm{R} \times \mathrm{S}$ & 1: 1 & 69 & 52 & 60.5 & 60.5 & 121 & 2.39 & 0.1222 \\
\hline
\end{tabular}

$\mathrm{R}=$ resistant reaction; $\mathrm{S}=$ susceptible reaction.

Table 4. Inheritance of resistance to downy mildew race $\mathrm{F}$ in lima bean populations derived from crosses of cultivars Maffei 15, B2C, and Jackson Wonder with genotypes categorized as resistant or susceptible.

\begin{tabular}{|c|c|c|c|c|c|c|c|c|c|}
\hline \multirow[b]{2}{*}{ Cross } & \multirow[b]{2}{*}{ Cross type } & \multirow[b]{2}{*}{ Test ratio } & \multicolumn{2}{|c|}{ Observed no. plants } & \multicolumn{2}{|c|}{ Expected no. plants } & \multirow[b]{2}{*}{ Total } & \multirow[b]{2}{*}{$\chi^{2}$ value } & \multirow[b]{2}{*}{$P$ value } \\
\hline & & & Resistant & Susceptible & Resistant & Susceptible & & & \\
\hline Jackson Wonder $\times$ Maffei $15 \mathrm{~F}_{2}$ & $\mathrm{~S} \times \mathrm{R}$ & $3: 1$ & 159 & 50 & 157 & 52 & 209 & 0.10 & 0.7490 \\
\hline Jackson Wonder $\times \mathrm{B} 2 \mathrm{C} \mathrm{F}_{2}$ & $\mathrm{~S} \times \mathrm{R}$ & $3: 1$ & 212 & 59 & 203 & 68 & 271 & 1.59 & 0.2073 \\
\hline
\end{tabular}

$\mathrm{R}=$ resistant reaction; $\mathrm{S}=$ susceptible reaction.

Table 5. Inheritance of resistance to downy mildew race F in lima bean populations derived from crosses of cultivars Maffei 15, B2C, and Jackson Wonder with genotypes categorized as resistant, moderately susceptible, or very susceptible.

\begin{tabular}{|c|c|c|c|c|c|c|c|}
\hline \multirow[b]{2}{*}{ Cross } & \multicolumn{4}{|c|}{ Number of plants } & \multicolumn{3}{|c|}{ Percent of plants } \\
\hline & Resistant & Moderately susceptible & Very susceptible & Total & Resistant & Moderately susceptible & Very susceptible \\
\hline Jackson Wonder $\times$ Maffei $15 \mathrm{~F}_{2}$ & 159 & 21 & 29 & 209 & 76 & 10 & 14 \\
\hline Jackson Wonder $\times \mathrm{B} 2 \mathrm{C} \mathrm{F}_{2}$ & 212 & 28 & 31 & 271 & 78 & 10 & 11 \\
\hline
\end{tabular}


produced by the USDA breeders who selected for resistance to downy mildew races $\mathrm{A}, \mathrm{B}, \mathrm{C}$, and D. The race E-resistant cultivar Dover Tucker is reported to be resistant to races A, B, and D (Stavely, 1991) and the race $\mathrm{F}$-resistant germplasm release $\mathrm{B} 2 \mathrm{C}$ is reported to be resistant to races $\mathrm{A}, \mathrm{B}, \mathrm{C}$, and D (Stavely, 1991).

Resistance to races $\mathrm{E}$ and $\mathrm{F}$ is also present in cultivars derived from the USDA's downy mildew-resistant germplasm releases. The cultivars Maffei 15 and Eastland are selections from B2C and C-elite Select and were derived from C-171 (PI 549513), which was a USDA germplasm release with resistance to races $\mathrm{A}, \mathrm{B}$, and $\mathrm{C}$. The original source of the race E-resistance gene is probably PI 189403, which was used in the USDA breeding program for resistance to races $\mathrm{A}, \mathrm{B}$, and D. The accession PI 195342, which is also resistant to races $\mathrm{A}, \mathrm{B}$, and $\mathrm{C}$, is the probable source of the race $\mathrm{F}$ resistance gene.

In these studies, the wild species $P$. polystachios was shown to be an alternate host of the downy mildew pathogen and the population of $P$. polystachios studied herein contained individuals with resistance to races $\mathrm{E}$ and $\mathrm{F}$. The resistance genes from $P$. polystachios will not likely be used directly for resistance breeding in lima bean because crosses between the two species do not produce stable diploid progeny (Lorz, 1971). However, additional characterization of the downy mildew resistance genes in this population may help us understand the mechanism for resistance in lima bean.

Resistance to race $\mathrm{E}$ is conferred by a single dominant gene and resistance to race
$\mathrm{F}$ is conferred by a different single dominant gene. A partial resistance reaction to race $F$ was also observed in resistant by susceptible test crosses and may be conferred by recessive or partially dominant genes. Only race $F$ has been detected in field samples since 2008 and consequently most of the breeding has been focused on the development of race F-resistant cultivars. The University of Delaware lima bean breeding program is currently trialing F-resistant breeding lines in the baby and Fordhook classes to determine whether they have commercially acceptable yield, quality, and horticultural characteristics. In addition, genetic markers for the race $\mathrm{F}$ resistance gene have been developed and are being tested. The partial resistance to race $F$, which was observed in the test crosses, will be characterized and mapped with the goal of using these genes to enhance the durability of downy mildew resistance in new lima bean cultivars.

\section{Literature Cited}

Calvert, O.H., L.F. Williams, and M.D. Whitehead. 1960. Frozen lima bean agar for culture and storage of Phytophthora sojae. Phytopathology 50:136-137.

Dance, M.H., F.J. Newhook, and J.S. Cole. 1975. Bioassay of Phytophthora spp. in soil. Plant Dis. Rptr. 59:523-527.

Delgado-Salinas, A., T. Turley, A. Richman, and M. Lavin. 1999. Phylogenetic analysis of the cultivated and wild species of Phaseolus (Fabaceae). Syst. Bot. 24:438-460.

Evans, T.A., C.R. Davidson, J.D. Dominiak, R.P. Mulrooney, R.B. Carroll, and S.H. Antonius. 2002. Two races of Phytophthora phaseoli from lima bean in Delaware. Plant Dis. 86:813.
Evans, T.A., R.P. Mulrooney, N. Gregory, and W.E. Kee. 2007. Lima bean downy mildew: Etiology, and management strategies for Delaware and the mid-Atlantic Region. Plant Dis. 91:128-135.

Evans, T.A., R.P. Mulrooney, and L. Santamaria 2005. Development of races of Phytophthora phaseoli, the causal agent of downy mildew of lima bean (Phaseolus lunatus) and the development of resistance. Annu. Rpt. Bean Improvement Coop. 49:15-16.

Kee, W.E., J.L. Glancey, Jr., and T.L. Wootten 1997. The lima bean: A vegetable crop for processing. HortTechnology 7:119-128.

Kirk, P.M., P.F. Cannon, J.C. David, and J.A. Stapler. 2001. Dictionary of the fungi. 9th ed. CABI Publishers, Wallingford, Oxon, UK.

Lorz, A.P. 1971. Progress report on "Lunastachyus" amphidiploid derivatives from $P$. lunatus $\times P$. polystachyus. Annu. Rpt. Bean Improvement Coop. 14:46-47.

Scuse, M.T. and T. Feurer. 2003. Delaware agricultural statistics summary for 2001-2002. Delaware Dept. Agr., Dover, DE.

Stavely, J.R. 1991. Lima bean (Phaseolus lunatus L.) development at Beltsville. Annu. Rpt. Bean Improvement Coop. 34:155-156.

Thomas, C.A. and V.L. Blount. 1976. Race D of Phytophthora phaseoli. Plant Dis. Rptr. 60:308.

Thomas, C.A. and V.J. Fisher. 1979. Registration of C-171 lima bean germplasm (reg. no. GP15). Crop Sci. 19:149.

Thomas, C.A. and V.J. Fisher. 1980. Registration of B2C lima bean germplasm (reg. no. GP30) Crop Sci. 20:553.

Wester, R.E. 1970. A new race of downy mildew on lima beans. Phytopathology 60:1856.

Wester, R.E. and R.C. Cetas. 1959. Breeding lima beans for resistance to downy mildew. Plant Dis. Rptr. Suppl. 257:181-182. 